\title{
Our gratitude to outgoing Editor-in-Chief Andrew Leach and a hearty welcome to new Editor-in-Chief, Richards Lewis
}

\author{
Terry R. Stouch
}

Received: 7 August 2012/Accepted: 3 September 2012/Published online: 16 September 2012

(C) Springer Science+Business Media B.V. 2012

It is with regret that we at the Journal of Computer-Aided Molecular Design accept Andrew Leach's resignation as co-Editor-in-Chief. Andrew has been dutifully serving the authors and readership of JCAMD for 13 years. During that time he has handled upwards of 1,000 papers; evaluating them, choosing and corresponding with reviewers, and making final rulings. Often, if a manuscript was missing features required by JCAMD editorial policy, he was generous with his time and helped authors to get their papers publication ready. Andrew came to JCAMD with the perfect background: he had a long history of applied computer-aided drug design and literally "wrote the book" on computational chemistry. Interestingly, he published in Volume 1, Issue 1 of JCAMD long before he assumed editorial duties. Andrew has assumed new responsibilities at his long-time employer, GlaxoSmithKline, that take him out of the daily practice of computational chemistry and computer-aided drug design. He will be missed. Fortunately for us, he has agreed to continue reviewing papers and will continue with us by serving on our Editorial Board. Please join us at Springer and JCAMD in offering heartfelt thanks to Andrew for his long and diligent service to the JCAMD community.

Andrew's shoes will be difficult to fill, but we are fortunate that Richard Lewis of Novartis Pharma, Basel, Switzerland has agreed to take on the burden. Richard was previously known to us, came highly recommended, and was seconded by many on our Editorial Board. He has long experience in CADD and is well-known in the CADD community. He studied at Cambridge, undertook his $\mathrm{PhD}$ with Philip Dean followed by post-doctoral research with Irwin ("Tack") Kuntz at UCSF as a Fulbright Senior Scholar and then with Michael Sternberg at Imperial College London. His subsequent successive positions at Rhone-Poulenc Rorer, Eli Lilly, and currently, Novartis, give him detailed insight into the many different technologies used by our authors and the types of applied problems they are investigating. His own experience with publishing makes him familiar with the process and sympathetic with the issues faced by authors, reviewers, and readers alike. Please join us in welcoming Richard to the JCAMD team.

Terry R. Stouch, Senior Editor-in-Chief

Federico Gago, Editor-in-Chief

Yvonne Martin, Editor, Perspectives in Drug Discovery and Design

Wendy Warr, Correspondent

Jenifer Sahayaraj, Springer, Journals Editorial Office Assistant

Baskaran Parasuraman, Springer, Production Editor

Meran Owen, Springer, Senior Publishing Editor

T. R. Stouch $(\square)$

Journal of Computer-Aided Molecular Design, West Windsor, NJ, USA

e-mail: tstouch@gmail.com 